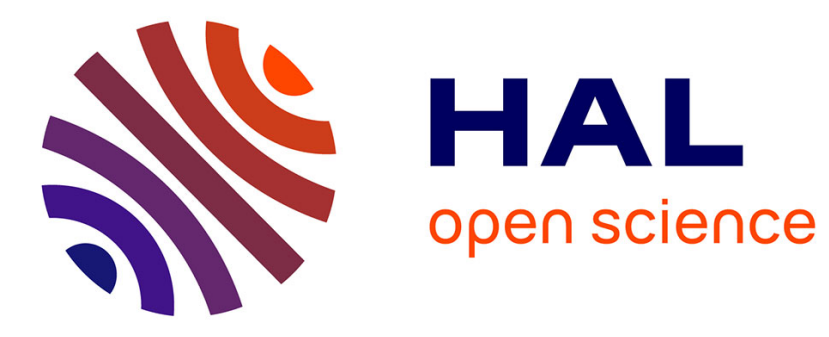

\title{
Saccharothrix hoggarensis sp. nov., an actinomycete isolated from Saharan soil
}

Dalila Boubetra, Abdelghani Zitouni, Noureddine Bouras, Florence Mathieu, Ahmed Lebrihi, Peter Schumann, Cathrin Spröer, Hans-Peter Klenk, Nasserdine Sabaou

\section{To cite this version:}

Dalila Boubetra, Abdelghani Zitouni, Noureddine Bouras, Florence Mathieu, Ahmed Lebrihi, et al.. Saccharothrix hoggarensis sp. nov., an actinomycete isolated from Saharan soil. International Journal of Systematic and Evolutionary Microbiology, 2013, 63 (2), pp.549-553. 10.1099/ijs.0.039099-0 . hal01335781

\section{HAL Id: hal-01335781 \\ https://hal.science/hal-01335781}

Submitted on 22 Jun 2016

HAL is a multi-disciplinary open access archive for the deposit and dissemination of scientific research documents, whether they are published or not. The documents may come from teaching and research institutions in France or abroad, or from public or private research centers.
L'archive ouverte pluridisciplinaire HAL, est destinée au dépôt et à la diffusion de documents scientifiques de niveau recherche, publiés ou non, émanant des établissements d'enseignement et de recherche français ou étrangers, des laboratoires publics ou privés. 


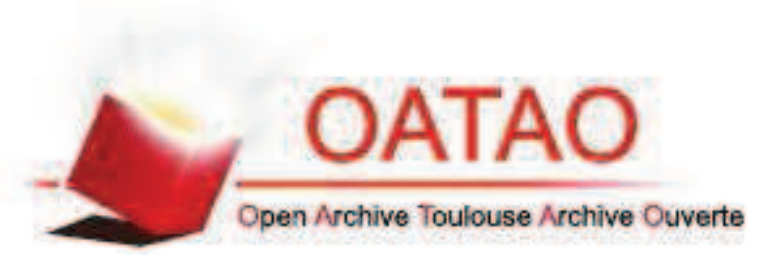

\section{Open Archive TOULOUSE Archive Ouverte (OATAO)}

OATAO is an open access repository that collects the work of Toulouse researchers and makes it freely available over the web where possible.

This is an author-deposited version published in : http://oatao.univ-toulouse.fr/ Eprints ID : 10815

To link to this article : DOI : 10.1099/ijs.0.039099-0

URL : http://dx.doi.org/10.1099/ijs.0.039099-0

To cite this version : Boubetra, Dalila and Zitouni, Abdelghani and Bouras, Noureddine and Mathieu, Florence and Lebrihi, Ahmed and Schumann, Peter and Spröer, Cathrin and Klenk, Hans-Peter and Sabaou, Nasserdine Saccharothrix hoggarensis sp. nov., an actinomycete isolated from Saharan soil. (2013) International Journal of Systematic and Evolutionary Microbiology, vol. $63(\mathrm{Pt}$ 2). pp. 549-553. ISSN $\underline{1466-5026}$

Any correspondance concerning this service should be sent to the repository administrator: staff-oatao@,listes-diff.inp-toulouse.fr 


\title{
Saccharothrix hoggarensis sp. nov., an actinomycete isolated from Saharan soil
}

\author{
Dalila Boubetra, ${ }^{1}$ Abdelghani Zitouni, ${ }^{1}$ Noureddine Bouras, ${ }^{1}$ \\ Florence Mathieu, ${ }^{2}$ Ahmed Lebrihi, ${ }^{2}$ Peter Schumann, ${ }^{3}$ Cathrin Spröer, ${ }^{3}$ \\ Hans-Peter Klenk ${ }^{3}$ and Nasserdine Sabaou ${ }^{1}$ \\ ${ }^{1}$ Laboratoire de Biologie des Systèmes Microbiens (LBSM), Ecole Normale Supérieure de Kouba, \\ BP 92, 16050 Kouba, Algiers, Algeria \\ 2Université de Toulouse, INPT-ENSAT, Laboratoire de Génie Chimique, UMR 5503 (CNRS/INPT/ \\ UPS), 1 Avenue de l'Agrobiopole BP 32607 Auzeville Tolosane 31326 Castanet-Tolosan, France \\ ${ }^{3}$ DSMZ - German Collection of Microorganisms and Cell Cultures, Inhoffenstraße 7B, 38124 \\ Braunschweig, Germany
}

Correspondence Nasserdine Sabaou sabaou@yahoo.fr
The genus Saccharothrix was described for the first time by Labeda et al. (1984). Several species of this genus have been transferred to other new taxa, including the genera Lentzea (Yassin et al., 1995), Crossiella (Labeda, 2001), Lechevalieria (Labeda et al., 2001), Goodfellowia (Labeda \& Kroppenstedt, 2006) and Umezawaea (Labeda \& Kroppenstedt, 2007). Currently, 12 species of the genus Saccharothrix have been described based on chemical analysis, physiological properties, cellular fatty acid composition, phylogeny and DNADNA hybridization data. The genus is characterized by fragmentation of both substrate and aerial mycelia into rods and ovoid elements, type III cell-wall meso-diaminopimelic acid without glycine, galactose, rhamnose and small amounts of mannose as diagnostic whole-cell sugars, a phospholipid type PII (phosphatidylethanolamine) or PIV (phosphatidylethanolamine and glucosamine-containing phospholipids) pattern (Labeda \& Lechevalier, 1989), the presence of MK$9\left(\mathrm{H}_{4}\right)$ as the predominant menaquinone and the absence of mycolic acids (Labeda \& Kroppenstedt, 2000).

During a study of Saharan actinomycetes, strain SA $181^{\mathrm{T}}$ was isolated from a soil sample from Tamanrasset $\left(22^{\circ} 47^{\prime}\right.$

The GenBank/EMBL/DDBJ accession number for the $16 \mathrm{~S}$ rRNA gene sequence of strain $\mathrm{SA} 181^{\top}$ is $\mathrm{HQ399564.}$

Two supplementary figures are available with the online version of this paper. $\left.0^{\prime \prime} \mathrm{N} 5^{\circ} 31^{\prime} 0^{\prime \prime} \mathrm{E}\right)$, an arid area in the south of Algeria (Hoggar), by a dilution-plating method using humic acidvitamin agar (Hayakawa \& Nonomura, 1987) supplemented with $50 \mu \mathrm{g}$ actidione $\mathrm{ml}^{-1}$.

Cultural characteristics were investigated on media from the International Streptomyces Project (ISP; Shirling \& Gottlieb, 1966), nutrient agar and Bennett's agar (Waksman, 1961). The degree of growth, aerial mycelia, pigmentation and other features were recorded after 7, 14 and 21 days of incubation at $30{ }^{\circ} \mathrm{C}$. Peptone-yeast extractiron agar (ISP 6) and tyrosine agar (ISP 7) were used to determine melanoid pigment production. The colours of substrate and aerial mycelia and any soluble pigments produced were determined according to the ISCC-NBS centroid colour chart (Kelly \& Judd, 1976). Strain SA181 ${ }^{\mathrm{T}}$ exhibited good growth on ISP 2, ISP 3, ISP 4, nutrient agar and Bennett's agar, with greyish blue, yellowish white and pinkish brown aerial mycelium on ISP 2, nutrient agar and Bennett's agar, respectively. No aerial mycelium was observed on ISP 3 or ISP 4. The colour of substrate mycelium was pale to light yellow on nutrient agar, moderate to deep yellowish brown on ISP 2 and ISP 4, light brown on Bennett's agar and dark brown on ISP 3. The substrate mycelium was fragmented into non-motile rods. The isolate did not produce diffusible or melanoid pigments. Spores and mycelia were examined by light 
microscopy (B1 series; Motic) and scanning electron microscopy after 2 weeks on ISP 2. The substrate mycelium exhibited an abundant fragmentation on both solid and liquid media. The aerial mycelium was fragmented into rod-shaped spores $(0.8-1.0 \times 1.0-1.5 \mu \mathrm{m})$. The spores had a smooth surface (Fig. 1) and were non-motile. No endospores, sporangia, sclerotia or synnemata were observed.

Chemotaxonomic characteristics were studied using biomass obtained after 4 days of incubation at $30{ }^{\circ} \mathrm{C}$ in shake flasks containing ISP 2 , harvested by centrifugation and washed several times with distilled water. The isomeric form of diaminopimelic acid and predominant whole-cell sugars were detected following standard procedures described by Becker et al. (1964) and Lechevalier \& Lechevalier (1970). Phospholipids and mycolic acids were analysed using the procedure of Minnikin et al. (1977, 1980). The fatty acid composition was determined by the method of Sasser (1990), using the TSBA40 database in the Sherlock Microbial Identification System version (MIDI) version Sherlock 6.1. The menaquinones were extracted following the procedure of Minnikin et al. (1984) and analysed by HPLC (Kroppenstedt, 1982, 1985). Strain SA $181^{\mathrm{T}}$ contained meso-diaminopimelic acid with alanine and glutamic acid, but not glycine. The whole-cell hydrolysates contained galactose, rhamnose, traces of mannose and ribose, typical of cell-wall type IIIE (Stackebrandt et al., 1994). The diagnostic phospholipid detected was phosphatidylethanolamine, which corresponds to phospholipid type PII (Lechevalier et al., 1977) (Fig. S1, available in IJSEM Online). Mycolic acids were not detected. The predominant fatty acid was iso-branched hexadecanoate (iso- $\mathrm{C}_{16: 0}$ ), and significant amounts of iso- $\mathrm{C}_{15: 0}$, 9-methyl- $\mathrm{C}_{16: 0}$, anteiso$\mathrm{C}_{17: 0}$, iso- $\mathrm{C}_{16: 1} \mathrm{H}$, iso- $\mathrm{C}_{16: 0} 2-\mathrm{OH}$, anteiso- $\mathrm{C}_{15: 0}$, iso- $\mathrm{C}_{17: 0}$,

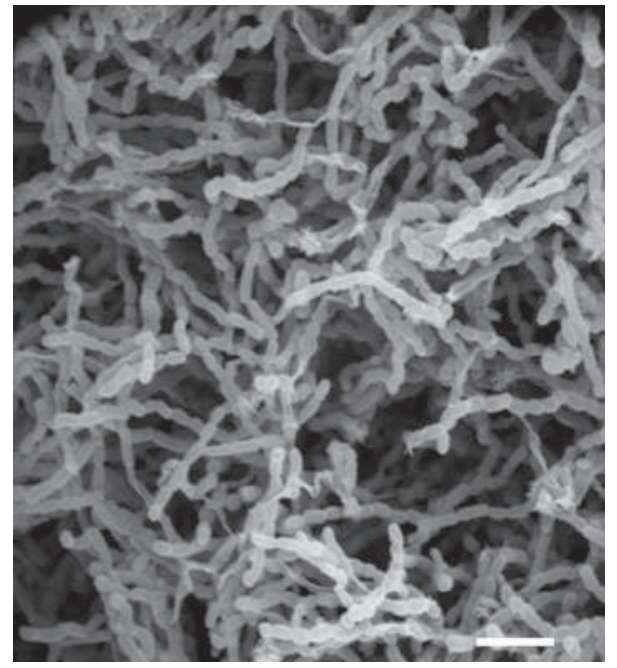

Fig. 1. Scanning electron micrograph of spore chains of strain $\mathrm{SA} 181^{\top}$ grown on yeast extract-malt extract agar (ISP 2) for 10 days at $30^{\circ} \mathrm{C}$. Bar, $5 \mu \mathrm{m}$. cis9- $\mathrm{C}_{17: 1}$ and anteiso- $\mathrm{C}_{17: 0}$ 2-OH were also detected (Table 1). Furthermore, a small fraction $(3.04 \%)$ of iso- $\mathrm{C}_{15: 0} 2-\mathrm{OH}$ could be detected in summed feature 4. Strain $\mathrm{SA} 181^{\mathrm{T}}$ contained menaquinones MK-9 $\left(\mathrm{H}_{4}\right)$, MK-7 $\left(\mathrm{H}_{4}\right)$, MK$10\left(\mathrm{H}_{4}\right), \mathrm{MK}-10\left(\mathrm{H}_{0}\right)$ and $\mathrm{MK}-11\left(\mathrm{H}_{4}\right)(55,12,9,3$ and $2 \%$, respectively, with traces of MK-9 $\left(\mathrm{H}_{0}\right), \mathrm{MK}-9\left(\mathrm{H}_{2}\right)$, MK$9\left(\mathrm{H}_{6}\right)$ and $\mathrm{MK}-10\left(\mathrm{H}_{2}\right)$. The morphological and chemical characteristics described above clearly support the placement of strain SA $181^{\mathrm{T}}$ within the genus Saccharothrix.

Media and procedures for the determination of physiological features and carbon source utilization have been described by Gordon et al. (1974) and Williams et al. (1989). The results showed that strain SA $181^{\mathrm{T}}$ is physiologically different from its closest neighbours in the genus Saccharothrix, as can be seen from the differential characters given in Table 2. The physiological characteristics of strain $\mathrm{SA} 181^{\mathrm{T}}$ are given in the species description.

Genomic DNA was extracted with a DNA extraction kit (MasterPure Gram Positive DNA Purification kit; Epicentre Biotechnologies). PCR-mediated amplification of the 16S rRNA gene was performed as described by Rainey et al. (1996). The sequence obtained was compared with sequences in public databases as well as in the EzTaxon-e server (http://eztaxon-e.ezbiocloud.net/; Kim et al., 2012), a web-based tool for the identification of

Table 1. Cellular fatty acid compositions of strain $\mathrm{SA} 181^{\top}$ and its most closely related neighbours in the genus Saccharothrix

Strains: 1, Saccharothrix hoggarensis sp. nov. SA $181^{\mathrm{T}} ; 2$, S. longispora DSM $43749^{\mathrm{T}}$; 3, S. texasensis DSM $44231^{\mathrm{T}}$; 4, S. xinjiangensis DSM $44896^{\mathrm{T}}$. All data were taken from this study. $\mathrm{G}$ and $\mathrm{H}$ indicate that the double bonds are in different locations. Fatty acid identities were determined using the TSBA40 database in the Sherlock Microbial Identification System version 6.1.

\begin{tabular}{|c|c|c|c|c|}
\hline Fatty acid (\%) & 1 & 2 & 3 & 4 \\
\hline iso- $\mathrm{C}_{14: 0}$ & 1.34 & 5.40 & 2.76 & 2.80 \\
\hline $\mathrm{C}_{14: 0}$ & - & 3.17 & - & 0.15 \\
\hline iso- $\mathrm{C}_{15: 0}$ & 14.87 & 14.60 & 23.97 & 5.70 \\
\hline anteiso- $\mathrm{C}_{15: 0}$ & 4.03 & 5.06 & 5.63 & 7.93 \\
\hline iso- $\mathrm{C}_{16: 1} \mathrm{H}$ & 6.81 & 3.72 & 4.55 & - \\
\hline iso- $\mathrm{C}_{16: 1} \mathrm{G}$ & - & - & - & 5.67 \\
\hline iso- $\mathrm{C}_{16: 0}$ & 27.00 & 24.63 & 24.73 & 24.89 \\
\hline cis $9-\mathrm{C}_{16: 1}$ & - & 1.64 & - & 6.94 \\
\hline $\mathrm{C}_{16: 0}$ & 0.27 & 6.40 & 0.26 & 1.19 \\
\hline 9-Methyl-C $16: 0$ & 9.45 & 2.13 & 4.59 & 2.66 \\
\hline iso- $\mathrm{C}_{17: 0}$ & 3.99 & 3.14 & 3.67 & 1.83 \\
\hline anteiso- $\mathrm{C}_{17: 0}$ & 9.38 & 4.37 & 4.35 & 9.04 \\
\hline cis $9-\mathrm{C}_{17: 1}$ & 3.72 & 6.60 & 4.90 & 13.18 \\
\hline iso- $\mathrm{C}_{16: 0} 2-\mathrm{OH}$ & 5.80 & - & 4.35 & 4.45 \\
\hline $\mathrm{C}_{17: 0}$ & 0.38 & 2.19 & 0.59 & 1.94 \\
\hline 10-Methyl- $C_{17: 0}$ & 1.03 & 0.47 & 3.55 & 1.50 \\
\hline cis $9-\mathrm{C}_{18: 1}$ & 0.46 & 7.71 & 0.22 & 3.41 \\
\hline anteiso- $\mathrm{C}_{17: 0} 2-\mathrm{OH}$ & 2.53 & - & 1.59 & 2.28 \\
\hline Summed feature 4 & 3.04 & - & - & - \\
\hline
\end{tabular}


Table 2. Differential phenotypic characteristics of strain $\mathrm{SA} 181^{\top}$ and its most closely related neighbours in the genus Saccharothrix

Strains: 1 , Saccharothrix hoggarensis sp. nov. $\mathrm{SA}_{181^{\mathrm{T}}} ; 2$, S. longispora DSM $43749^{\mathrm{T}}$; 3, S. texasensis DSM $44231^{\mathrm{T}}$; 4, S. xinjiangensis DSM $44896^{\mathrm{T}}$. All data were taken from this study.

\begin{tabular}{|c|c|c|c|c|}
\hline Characteristic & 1 & 2 & 3 & 4 \\
\hline \multicolumn{5}{|l|}{ Decomposition of: } \\
\hline Adenine & - & + & - & - \\
\hline Hypoxanthine & + & - & + & + \\
\hline \multicolumn{5}{|l|}{ Production of: } \\
\hline Nitrate reductase & - & + & + & + \\
\hline \multicolumn{5}{|l|}{ Assimilation of: } \\
\hline Butyrate & + & - & + & - \\
\hline Citrate & - & + & - & - \\
\hline \multicolumn{5}{|l|}{ Acid from: } \\
\hline Inositol & - & - & + & + \\
\hline Lactose & - & + & + & + \\
\hline Mannitol & - & + & + & + \\
\hline Melibiose & + & - & + & + \\
\hline Methyl $\alpha$-D-glucoside & - & - & + & + \\
\hline Raffinose & - & - & + & + \\
\hline Salicin & - & + & - & - \\
\hline Sorbitol & + & - & - & - \\
\hline \multicolumn{5}{|l|}{ Growth at/with: } \\
\hline $45^{\circ} \mathrm{C}$ & + & - & - & - \\
\hline $4 \%(\mathrm{w} / \mathrm{v}) \mathrm{NaCl}$ & + & - & + & - \\
\hline $5 \%(\mathrm{w} / \mathrm{v}) \mathrm{NaCl}$ & + & - & + & - \\
\hline
\end{tabular}

prokaryotes based on 16S rRNA gene sequences from type strains. Phylogenetic analysis was conducted using MEGA version 5 (Tamura et al., 2011). The 16S rRNA gene sequence of strain $\mathrm{SA} 181^{\mathrm{T}}$ was aligned with neighbouring sequences using CLUSTAL $\mathrm{W}$ (with default parameters; Thompson et al., 1994). Phylogenetic trees were constructed by using neighbour-joining (Saitou \& Nei, 1987) with the model of Jukes \& Cantor (1969), maximumlikelihood (Felsenstein, 1981) with Kimura's two-parameter model (Kimura, 1980) and maximum-parsimony (Fitch, 1977). Bootstrap analysis (Felsenstein, 1985) was performed to evaluate the reliability of the tree topology.

The phylogenetic relationships between strain SA181 ${ }^{\mathrm{T}}$ and members of the genus Saccharothrix are shown in the neighbour-joining dendrogram (Fig. 2). Maximum-parsimony and maximum-likelihood calculations resulted in similar tree topologies (Fig. S2). The similarity of the $16 \mathrm{~S}$ rRNA gene sequence of strain SA $181^{\mathrm{T}}$ to those of other members of the genus Saccharothrix ranged from 96.8 to $98.9 \%$. Strain SA181 ${ }^{\mathrm{T}}$ displayed highest $16 \mathrm{~S}$ rRNA gene sequence similarity with Saccharothrix longispora NRRL B-16113 ${ }^{\mathrm{T}}$ (98.9\%), Saccharothrix xinjiangensis NBRC $101911^{\mathrm{T}}(98.4 \%)$ and Saccharothrix texasensis NRRL B$61634^{\mathrm{T}}(98.2 \%)$ and $16 \mathrm{~S}$ rRNA gene sequence similarities with the other remaining members of the genus Saccharothrix were below $97.9 \%$.
For DNA-DNA hybridization, cells were disrupted by using a French pressure cell (Thermo Spectronic). DNA in the crude lysate was purified by chromatography on hydroxyapatite as described by Cashion et al. (1977). DNA-DNA hybridization was carried out as described by De Ley et al. (1970) under consideration of the modifications described by Huss et al. (1983), using a model Cary 100 Bio UV/VIS spectrophotometer equipped with a Peltier-thermostatted $6 \times 6$ multicell changer and a temperature controller with insitu temperature probe (Varian). DNA-DNA hybridization experiments were done in duplicate in $2 \times$ SSC in the presence of $10 \%$ formamide at $71{ }^{\circ} \mathrm{C}$. DNA of strain SA $181^{\mathrm{T}}$ was hybridized with that of its closest phylogenetic neighbours. Mean DNA-DNA relatedness values between strain SA181 $1^{\mathrm{T}}$ and S. longispora DSM $43749^{\mathrm{T}}$, S. texasensis DSM $44231^{\mathrm{T}}$ and S. xinjiangensis DSM $44896^{\mathrm{T}}$ were $16.05 \%$ (14.7 and $17.4 \%$ ), $50.05 \%$ (46.5 and $53.6 \%$ ) and $22.0 \%$ (24.2 and $19.8 \%)$, respectively, which are clearly below the $70 \%$ threshold proposed by Wayne et al. (1987) for the delineation of separate species.

A comparison of physiological characteristics of the isolate and S. longispora DSM $43749^{\mathrm{T}}$ showed differences in the utilization of adenine, hypoxanthine, sodium butyrate, sodium citrate, lactose, mannitol, melibiose, salicin and sorbitol, production of nitrate reductase, growth at $45{ }^{\circ} \mathrm{C}$ and with 4 and $5 \%(\mathrm{w} / \mathrm{v}) \mathrm{NaCl}$. Furthermore, S. texasensis DSM $44231^{\mathrm{T}}$ showed differences in the utilization of inositol, lactose, mannitol, methyl $\alpha$-D-glucoside, raffinose and sorbitol, production of nitrate reductase and growth at $45{ }^{\circ} \mathrm{C}$, and S. xinjiangensis DSM $44896^{\mathrm{T}}$ showed differences in the utilization of sodium butyrate, inositol, lactose, mannitol, methyl $\alpha$-D-glucoside, raffinose and sorbitol, production of nitrate reductase and growth at $45{ }^{\circ} \mathrm{C}$ and with 4 and $5 \%(\mathrm{w} / \mathrm{v}) \mathrm{NaCl}$.

Recently, 'Saccharothrix yanglingensis' was described (Yan et al., 2012). Strain SA181 ${ }^{\mathrm{T}}$ differs from that species in several morphological and physiological characteristics, including colour of substrate and aerial mycelia, production of diffusible pigment, degradation of gelatin, hypoxanthine and tyrosine, reduction of nitrate, use of arabinose, lactose, melibiose, rhamnose, xylose and sorbitol and growth at $\mathrm{pH} 5$, at $45{ }^{\circ} \mathrm{C}$ and in the presence of $4 \%(\mathrm{w} /$ v) $\mathrm{NaCl}$. Unlike strain $\mathrm{SA} 181^{\mathrm{T}}$, 'S. yanglingensis' contains no rhamnose in its whole cell.

All data support the conclusion that strain $\mathrm{SA} 181^{\mathrm{T}}$ represents a novel species of the genus Saccharothrix, for which we propose the name Saccharothrix hoggarensis sp. nov.

\section{Description of Saccharothrix hoggarensis sp. nov.}

Saccharothrix hoggarensis (hog.gar.en'sis. N.L. fem. adj. hoggarensis pertaining to Hoggar, the source of the soil from which the type strain was isolated).

Aerobic, Gram-positive, filamentous actinomycete. Aerial mycelium is light greyish blue on ISP 2, yellowish white on 


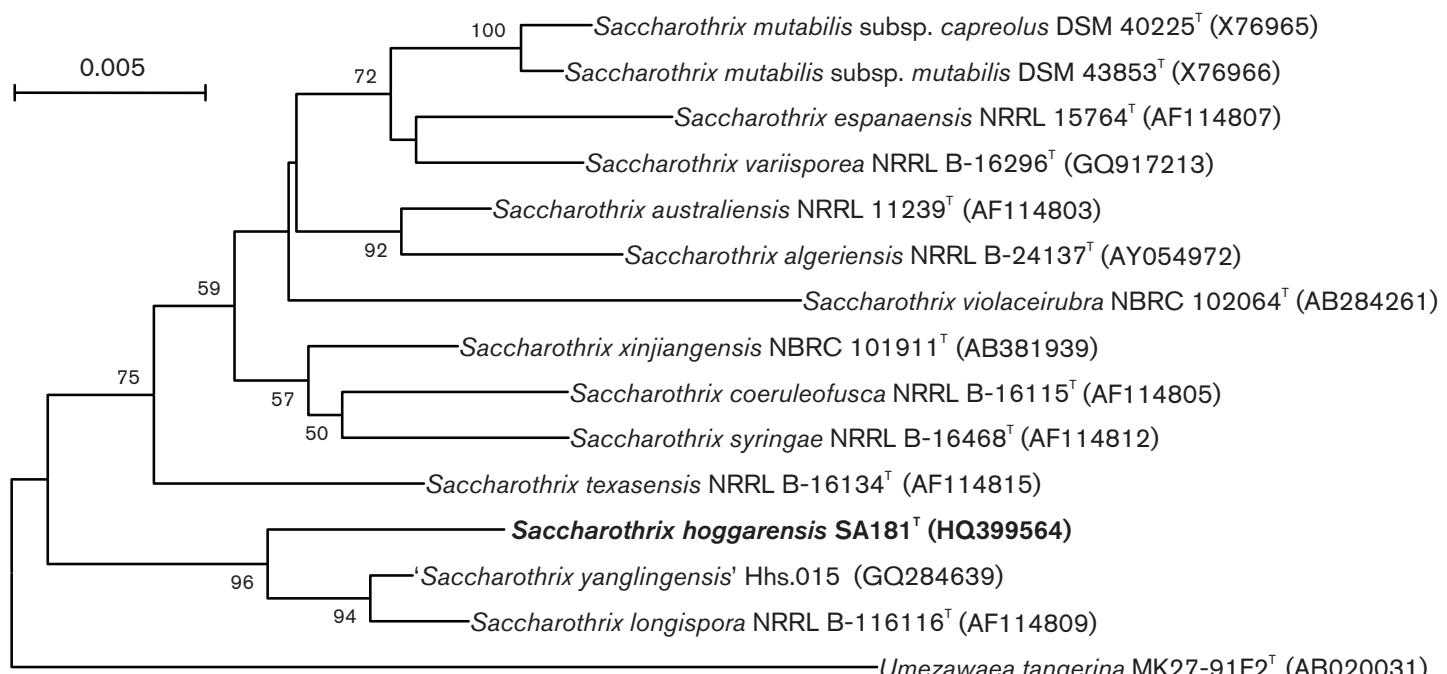

Fig. 2. Neighbour-joining phylogenetic tree based on almost-complete $16 \mathrm{~S}$ rRNA gene sequences showing the position of strain $\mathrm{SA} 181^{\top}$ in the genus Saccharothrix. This illustrates the taxonomic position of strain $\mathrm{SA} 181^{\top}$ relative to the other species of the genus, including 'Saccharothrix yanglingensis' (Yan et al., 2012). Bootstrap values (>50\%) based on 1000 resamplings are shown at branch nodes. Bar, 0.005 substitutions per site.

nutrient agar and pinkish brown on Bennett's agar and is well fragmented into rod-shaped spores $(0.8-1.0 \times 1.0-$ $1.5 \mu \mathrm{m})$. Substrate mycelium is pale to light yellow on nutrient agar, moderate to deep yellowish brown on ISP 2 and ISP 4, light brown on Bennett's agar and dark brown on ISP 3. The substrate mycelium fragments into non-motile rods. Diffusible and melanoid pigments are not produced. Growth occurs at $20-45{ }^{\circ} \mathrm{C}$ (optimum $30{ }^{\circ} \mathrm{C}$ ), but not $10{ }^{\circ} \mathrm{C}$, at $\mathrm{pH}$ 6-9 (optimum $\mathrm{pH} 7$ ), but not at $\mathrm{pH} 5$ or 11 , and with $4-5 \%(\mathrm{w} / \mathrm{v}) \mathrm{NaCl}$, but not with $7 \%$. Aesculin, casein, gelatin, hypoxanthine, Tween 80 , starch, tyrosine and urea are degraded, but adenine, arbutin, testosterone and xanthine are not. Utilizes L-arabinose, cellobiose, D-fructose, D-galactose, D-glucose, glycerol, maltose, melibiose, Dribose, L-rhamnose, D-sorbitol, sucrose, D-xylose, acetate, butyrate, lactate, propionate, pyruvate and succinate as carbon sources, but adonitol, lactose, D-mannitol, melezitose, myo-inositol, D-mannose, methyl $\alpha$-D-glucoside, raffinose, salicin, trehalose, benzoate, citrate, oxalate and tartrate are not utilized. L-Proline is used as a source of nitrogen, but L-alanine and L-serine are not utilized. Nitrate reductase is not produced. Resistant to $\left(\mu \mathrm{g} \mathrm{ml}^{-1}\right)$ chloramphenicol (30), erythromycin (15) and novobiocin (5). The cell wall is type IIIE (meso-diaminopimelic acid, galactose, mannose, rhamnose and ribose in whole-cell hydrolysates). Exhibits phospholipid type PII (phosphatidylethanolamine, with phosphatidylmethylethanolamine, phosphatidylinositol, phosphatidylinositol mannosides and diphosphatidylglycerol). The predominant menaquinones are MK- $9\left(\mathrm{H}_{4}\right)$, MK-7 $\left(\mathrm{H}_{4}\right), \mathrm{MK}-10\left(\mathrm{H}_{4}\right), \mathrm{MK}-10\left(\mathrm{H}_{0}\right)$ and MK-11 $\left(\mathrm{H}_{4}\right)$, with traces of MK-9 $\left(\mathrm{H}_{0}\right)$, MK-9 $\left(\mathrm{H}_{2}\right)$, MK- $9\left(\mathrm{H}_{6}\right)$ and MK$10\left(\mathrm{H}_{2}\right)$. The major fatty acids are iso- $\mathrm{C}_{16: 0}$, iso- $\mathrm{C}_{15: 0}$, 9methyl- $\mathrm{C}_{16: 0}$ and anteiso- $\mathrm{C}_{17: 0}$.
The type strain is $\mathrm{SA} 181^{\mathrm{T}}\left(=\mathrm{DSM} 45457^{\mathrm{T}}=\mathrm{CCUG}\right.$ $60214^{\mathrm{T}}$ ), isolated from a Saharan soil sample collected from Hoggar region (south Algeria).

\section{Acknowledgements}

We would like to gratefully acknowledge the help of Gabriele Pötter (DSMZ) for growing S. hoggarensis cultures and for assistance with chemotaxonomic analyses and Bettina Sträubler for assistance with DNA-DNA hybridizations.

\section{References}

Becker, B., Lechevalier, M. P., Gordon, R. E. \& Lechevalier, H. A. (1964). Rapid differentiation between Nocardia and Streptomyces by paper chromatography of whole-cell hydrolysates. Appl Microbiol 12, 421-423.

Cashion, P., Holder-Franklin, M. A., McCully, J. \& Franklin, M. (1977). A rapid method for the base ratio determination of bacterial DNA. Anal Biochem 81, 461-466.

De Ley, J., Cattoir, H. \& Reynaerts, A. (1970). The quantitative measurement of DNA hybridization from renaturation rates. Eur J Biochem 12, 133-142.

Felsenstein, J. (1981). Evolutionary trees from DNA sequences: a maximum likelihood approach. J Mol Evol 17, 368-376.

Felsenstein, J. (1985). Confidence limits on phylogenies: an approach using the bootstrap. Evolution 39, 783-791.

Fitch, W. M. (1977). On the problem of discovering the most parsimonious tree. Am Nat 111, 223-257.

Gordon, R. E., Barnett, D. A., Handerhan, J. E. \& Pang, C. H. N. (1974). Nocardia coeliaca, Nocardia autotrophica, and the nocardin strain. Int J Syst Bacteriol 24, 54-63.

Hayakawa, M. \& Nonomura, H. (1987). Humic acid-vitamin agar, a new medium for the selective isolation of soil actinomycetes. J Ferment Technol 65, 501-509. 
Huss, V. A. R., Festl, H. \& Schleifer, K. H. (1983). Studies on the spectrophotometric determination of DNA hybridization from renaturation rates. Syst Appl Microbiol 4, 184-192.

Jukes, T. H. \& Cantor, C. R. (1969). Evolution of protein molecules. In Mammalian Protein Metabolism, pp. 21-132. Edited by H. N. Munro. New York: Academic Press.

Kelly, K. L. \& Judd, D. B. (1976). Color: Universal Language and Dictionary of Names (National Bureau of Standards Special Publication 440). Washington, DC: US Department of Commerce.

Kim, O. S., Cho, Y. J., Lee, K., Yoon, S. H., Kim, M., Na, H., Park, S. C., Jeon, Y. S., Lee, J. H. \& other authors (2012). Introducing EzTaxon-e: a prokaryotic $16 \mathrm{~S}$ rRNA gene sequence database with phylotypes that represent uncultured species. Int J Syst Evol Microbiol 62, 716-721.

Kimura, M. (1980). A simple method for estimating evolutionary rates of base substitutions through comparative studies of nucleotide sequences. J Mol Evol 16, 111-120.

Kroppenstedt, R. M. (1982). Separation of bacterial menaquinones by HPLC using reverse phase (RP18) and a silver loaded ion exchanger as stationary phases. J Liq Chromatogr 5, 2359-2367.

Kroppenstedt, R. M. (1985). Fatty acid and menaquinone analysis of actinomycetes and related organisms. In Chemical Methods in Bacterial Systematics, pp. 173-179. Edited by M. Goodfellow \& D. E. Minnikin. London: Academic Press.

Labeda, D. P. (2001). Crossiella gen. nov., a new genus related to Streptoalloteichus. Int J Syst Evol Microbiol 51, 1575-1579.

Labeda, D. P. \& Kroppenstedt, R. M. (2000). Phylogenetic analysis of Saccharothrix and related taxa: proposal for Actinosynnemataceae fam. nov. Int J Syst Evol Microbiol 50, 331-336.

Labeda, D. P. \& Kroppenstedt, R. M. (2006). Goodfellowia gen. nov., a new genus of the Pseudonocardineae related to Actinoalloteichus, containing Goodfellowia coeruleoviolacea gen. nov., comb. nov. Int $J$ Syst Evol Microbiol 56, 1203-1207.

Labeda, D. P. \& Kroppenstedt, R. M. (2007). Proposal of Umezawaea gen. nov., a new genus of the Actinosynnemataceae related to Saccharothrix, and transfer of Saccharothrix tangerinus Kinoshita et al. 2000 as Umezawaea tangerina gen. nov., comb. nov. Int J Syst Evol Microbiol 57, 2758-2761.

Labeda, D. P. \& Lechevalier, M. P. (1989). Amendment of the genus Saccharothrix Labeda et al. 1984 and descriptions of Saccharothrix espanaensis sp. nov., Saccharothrix cryophilis sp. nov., and Saccharothrix mutabilis comb. nov. Int J Syst Bacteriol 39, 420-423.

Labeda, D. P., Testa, R. T., Lechevalier, M. P. \& Lechevalier, H. A. (1984). Saccharothrix: a new genus of the Actinomycetales related to Nocardiopsis. Int J Syst Bacteriol 34, 426-431.

Labeda, D. P., Hatano, K., Kroppenstedt, R. M. \& Tamura, T. (2001). Revival of the genus Lentzea and proposal for Lechevalieria gen. nov. Int J Syst Evol Microbiol 51, 1045-1050.

Lechevalier, M. P. \& Lechevalier, H. A. (1970). Chemical composition as a criterion in the classification of aerobic actinomycetes. Int $J$ Syst Bacteriol 20, 435-443.

Lechevalier, M. P., de Bièvre, C. \& Lechevalier, H. A. (1977). Chemotaxonomy of aerobic actinomycetes: phospholipid composition. Biochem Syst Ecol 5, 249-260.

Minnikin, D. E., Patel, P. V., Alshamaony, L. \& Goodfellow, M. (1977). Polar lipid composition in the classification of Nocardia and related bacteria. Int J Syst Bacteriol 27, 104-117.
Minnikin, D. E., Hutchinson, I. G., Caldicott, A. B. \& Goodfellow, M. (1980). Thin-layer chromatography of methanolysates of mycolic acid-containing bacteria. J Chromatogr A 188, 221-233.

Minnikin, D. E., O'Donnell, A. G., Goodfellow, M., Alderson, G., Athalye, M., Schaal, A. \& Parlett, J. H. (1984). An integrated procedure for the extraction of bacterial isoprenoid quinones and polar lipids. J Microbiol Methods 2, 233-241.

Rainey, F. A., Ward-Rainey, N., Kroppenstedt, R. M. \& Stackebrandt, E. (1996). The genus Nocardiopsis represents a phylogenetically coherent taxon and a distinct actinomycete lineage: proposal of Nocardiopsaceae fam. nov. Int J Syst Bacteriol 46, 1088-1092.

Saitou, N. \& Nei, M. (1987). The neighbor-joining method: a new method for reconstructing phylogenetic trees. Mol Biol Evol 4, 406425.

Sasser, M. (1990). Identification of bacteria by gas chromatography of cellular fatty acids, MIDI Technical Note 101. Newark, DE: MIDI Inc.

Shirling, E. B. \& Gottlieb, D. (1966). Methods for characterization of Streptomyces species. Int J Syst Bacteriol 16, 313-340.

Stackebrandt, E., Kroppenstedt, R. M., Jahnke, K. D., Kemmerling, C. \& Qurther, H. (1994). Transfer of Streptosporangium viridogriseum (Okuda et al., 1966), Streptosporangium viridogriseum subsp. kofuensis (Nonomura, Ohara, 1969), Streptosporangium albidum (Furumal et al., 1968) to Kutzneria gen. nov. as Kutzneria viridogrisea comb. nov., Kutzneria kofuensis comb. nov., Kutzneria albida comb. nov., respectively, and Emendation of the genus Streptosporangium. Int $J$ Syst Bacteriol 44, 265-269.

Tamura, K., Peterson, D., Peterson, N., Stecher, G., Nei, M. \& Kumar, S. (2011). MEGA5: molecular evolutionary genetics analysis using maximum likelihood, evolutionary distance, and maximum parsimony methods. Mol Biol Evol 28, 2731-2739.

Thompson, J. D., Higgins, D. G. \& Gibson, T. J. (1994). CLUSTAL W: improving the sensitivity of progressive multiple sequence alignment through sequence weighting, position-specific gap penalties and weight matrix choice. Nucleic Acids Res 22, 4673-4680.

Waksman, S. A. (1961). The Actinomycetes, Classification, Identification, Descriptions of Genera and Species, vol. 2. Baltimore: Williams \& Wilkins.

Wayne, L. G., Brenner, D. J., Colwell, R. R., Grimont, P. A. D., Kandler, O., Krichevsky, M. I., Moore, L. H., Moore, W. E. C., Murray, R. G. E. \& other authors (1987). International Committee on Systematic Bacteriology. Report of the ad hoc committee on reconciliation of approaches to bacterial systematics. Int J Syst Bacteriol 37, 463464.

Williams, S. T., Goodfellow, M. \& Alderson, G. (1989). Genus Streptomyces Waksman and Henrici 1943, 339 ${ }^{\mathrm{AL}}$. In Bergey's Manual of Systematic Bacteriology, vol. 4, pp. 2452-2492. Edited by S. T. Williams, M. E. Sharpe \& J. G. Holt. Baltimore: Williams \& Wilkins.

Yan, X., Huang, L. L., Tu, X., Gao, X. N. \& Kang, Z. S. (2012). Saccharothrix yanglingensis sp. nov., an antagonistic endophytic actinomycete isolated from cucumber plant. Antonie van Leeuwenhoek 101, 141-146.

Yassin, A. F., Rainey, F. A., Brzezinka, H., Jahnke, K. D., Weissbrodt, H., Budzikiewicz, H., Stackebrandt, E. \& Schaal, K. P. (1995). Lentzea gen. nov., a new genus of the order Actinomycetales. Int J Syst Bacteriol 45, 357-363. 